\title{
The Strategical Employment of Cavalry
}

\author{
Lieut.-Colonel H. De la P. Gough p.s.c.
}

To cite this article: Lieut.-Colonel H. De la P. Gough p.s.c. (1905) The Strategical

Employment of Cavalry, Royal United Services Institution. Journal, 49:332, 1117-1137, DOI:

$10.1080 / 03071840509416620$

To link to this article: http://dx.doi.org/10.1080/03071840509416620

曲 Published online: 11 Sep 2009.

Submit your article to this journal

Џ Article views: 4

Q View related articles $\sqsubset$ 
THE

\title{
STRATEGICAL EMPLOYMENT OF CAVALRX.
}

\author{
By Lieut.-Colonel II. De la P. GOUGII, p.s.c., 10th (The Queen's) \\ Lancers.
}

Tuesday, 16th May, 1905.

Major-General R. S. S. Banen-Poweld, C.B. (Inspector-General of Cavalry), in the Chair.

The Cirararas :-It is my privilege to introduce to you this afternoon Lieut.-Colonel Gongh, the lecturer, and I may say that I am rery glad to see a good number of cavalry officers here, because it is a rather uinusual sight in this hall. We want more of them. I believe if more of them joined this Institution, and attended its meetings, they would find it very useful for them. There is a great deal of reading demanded from officers nowadays, and by becoming members of the Institution they would be able to face, with greater equanimity than in the past, the examinations that are such a terror to them at present. They would also see a good deal of other arms in the sister services, the Nary with its water-tight bulk-heads; the Infantry, the Artillery, the Engineers, and their respective methods and characteristics, and it rould open up their minds considerably. They would also learn to see themselves as others see them, and they would then realise that water-tight bulk-heads exist in other places besides the Navy. We are rather too much shut up in compartments at present, and $I$ think it would open up our minds to be more in this Institution. I regret to say that Lord Roberts is unable to be present this afternoon; but he has sent this letter to Colonel Gough, which I will read to you. After expressing his inability to be present, he says :- "There was, I believe, an idea at one time that the introduction of long-range weapons would render Cavalry less useful in war than rreviously, whereas the fact is, that the duties which will devolve on Cavalry in the future will be eren more important than in the past. It will be more difficult to obtain information of the enemy's morenents, which, as you say, is the main role of Caralry. Greater distances rill lave to be traversed, requiring the lorses to be more carefully looked after, and all ranks must be carefully trained. Armed with the modern rifle, Cavalry has an independence hitherto unlnown. As you remark, it possesses the porer of defence or of attack on foot without in the least degree losing any of its offensive value when mounted. I agree with what you urge about a greater proportion of Caralrs being required than in the past, its economical employment, and the necessity for an intimate knowledge on the part of commanders of the proper use to make of their Cavalry." I will not delay you further, but at once introduce the lecturer to you, who will address you on Cavalry Strategy, a subject which necessarily interests the majority of us here present.

voL, XLIX.

4 B 


\section{LECTURE.}

AFTER 1815, all the nations of Europe seemed to grow tired of war; and the military art, which had flourished so luxuriantly during the previous twenty years, fell into decay. No arm suffered so much on account of this general decline in military thought as the cavalry.

This was partly owing to the growing efficiency of fire-arms, which cavsed the superficial critics (who thought war was made up of battles) to lay down as a military axiom that the days of cavalry were over; and another cause which was tending to produce this same erroneous impression was that the employment of cavalry is essentially a great art, which requires for its full development the guiding hand of a skilled artist who is intimately acquainted with the principles governing its action.

During the majority of the wars since 1815 , this skilled artist, one who thoroughly understood how to use his tool, had not been found, owing largely to the decline in the study of war which seems to have taken place up to $1870 \mathrm{in}$ almost all countries except Germany.

The cavalry in consequence has been, more often than not, misdirected, and has been employed without any regard to the great strategical principles which govern its action. This has resulted in still further detracting from the importance of cavalry in the minds of those who have not made a very close study of war.

That this is a very serious error there is no doubt. Military criticism is always liable to dash into extremes, and one of the most dangerous extremes it has run into in England is that of belittling the value of cavalry.

Far from its importance having diminished on account of the improvement in firearms, a numerous, well-equipped, well-trained, and well-handled cavalry has become one of the most essential parts of all Armics. Its value, more especially in its strategic employment, has increased enormously.

It was reserved for the Americans chiefly to exemplify the importance of the strategic rôle of cavalry in this respect. It is very interesting to read an article by General von Pelet-Narbonne, a German cavalry general, a translation of which appeared in the Jounnal of the Institution last March, and in which he lays great stress on the value of the lessons to be learned from the United States cavalry. This is especially curious, emanating as it does from the pen of a German cavalry officer, because it has been the fashion in Germany and among those who look only to Germany for inspiration on cavalry matters, to depreciate the United States cavalry, and to assert that they would not for one minute have withstood European cavalry trained on the German methods. But the War of Secession showed how greatly the strategic value of cavalry has increased, when, owing to being armed with a good frearm, it possesses the power of defence or of attack on foot, witliout in the least degree losing any of its offensive value when mounted.

Cavalry is the great strategical arm, while infantry and artillery may more properly be styled the tactical arms. As such, cavalry is the special instrument in the hands of the Chief of the Whole Force; upon the use of it the success of nis strategy will largely depend. The value of information about the enemy has always been of transcendent importance; but with the enormous Armies that nations now put in 
the field the necessity of early information has become a vital necessity, for these largo numbers take far longer to put in motion and to concentrate on any one battle-field than the smaller numbers of the past.

Upon early information depend the power and liberty of the Chief of manœuvre, and on it also depends the mobility of the whole Army. For the mobility of an Army depends as much on prompt, clear, and definite orders emanating from headquarters as upon the marching power of the men; and orders will not be promptly issued or be clear and definite unless the Chief has the confidence based on the possession of ample and carly information. Without such information he will pass rapidly from confidence to uncertainty and fear. Anxiety of mind will act as a drag on all his movements, and he will be slow and hesitating. . Cavalry is the strategical instrument par excellence for this purpose, which is attained under two forms.

Thise two forms can be expressed by the terms "to discover" and "to cover," which condense the principles of the strategic employment of cavalry.

These principles, in a vague and indefinite form, have long been matters of common knowledge; but I think their application has not always been sufficiently studied. It is not sufficient for soldiers to know vaguely the principles governing the action of cavalry. They must study war, and see and understand for themselves the application of these principles.

The point that stands out clearest in their application is that to "discover," or the service of information, and to "cover," or the service of security, are two entirely distinct functions, which must never be confused together, and for each of which an entirely separate body of cavalry must be detailed. This absolute division in the duties of cavalry has long been recognised by military writers on the Continent, for the last 20 years at least, and yet it was only in the last somewhat abused edition of our "Cavalry Training" that this distinction came to be recognised. As late even as in the previous "Cavalry Drill Book" the confusion of ideas on this subject was very apparent.

The first essential for the proper performance of the two services, of information and of security, is the distribution of the cavalry throughout the Army.

Sufficient cavalry must be attached to every division and corps to eusure for them immunity from local surprise; in fact to perform for them the service of security. These bodies of cavalry will be required to make good the iront and flanks of the troops up to a distance of 2 or 3 miles, and to prevent the enemy's patrols penetrating as far as the main bodies, when the troops are either on the march or laited. The number of cavalry attached for these duties should be the minimum sufficient to carry them out properly, leaving the remainder of the cavalry to form as large a mass as possible, divided into brigades, divisions, and even corps; to carry out the great. strategical róle of cavalry, namely, the service of information. This mass of cavalry must be under the direct orders of the Chief of the Whole Force, and it is his special strategical instrument.

Of course, when army corps or armies are detached and acting separately, it will be advisable to add some extra cavalry to them for the sole purpose of providing them with information; but the Chief should always keep a mass of cavalry in his own hand, to act under his own particular directions. 
This-was always the custom of Napoleon; it was the custom of Iee and Jackson and Grant; and it was in the neglect to provide this instrument that the German General Staff first laid themselves open. to criticism in their lhandling of the cavalry, both in 1866 and 1870 .

At the opening of both these campaigns, the Germans were divided into three armies. Each of these armies had a cavalry regiment attached to each infantry division, and in addition a certain number of cavalry divisions and brigades; but there was not a single cavalry soldier under the direct orders of the German Headquarters. There was not a single mounted man whom Moltke could employ on any particular mission of his own.

Any information that reached him came through one or other of his Army Commanders. They very naturally used their cavalry entirely from the point of view of their own particular interests, and also in accordance with their capacity and their appreciation of the use of this arm:

In 1866 the knowledge of cavalry of all three Army Commanders. was limited, and the cavairy divisions, instead of moving far to the front, obtaining early information of the enemy's dispositions and movements, and ensuring the co-operation between the separated armies, marched slowly and painfully with the infantry columns, and the only reconnaissances attempted were carried out by the divisional cavalry, who were of course tied to the heads of their infantry divisions, with a very limited range for exploration. In 1870 , two out of the three commanders had no idea at first of using their cavalry at all, and the information that reached Moltke was very meagre, and he suffered some anxious moments in consequence, while the armies suffered from some unnecessary counter-marches and delays owing either to misleading information, or to lack of it altogether.

Moltke in these two campaigns depended, therefore, largely for his information on how his subordinate commanders employed their cavalry, and he himself could not direct any body of cavalry on any particular objective at any given moment to find out what was there. Nor could he dispose of any mass of cavalry with which to cover the strategical concentration or mancuvres of his three armies.

This is the great rôle of modern cavalry, namely, to obtain early information and to cover the strategic manouvres of the army. The service of direct security having been provided for by attaching small bedies of cavalry to divisions and army corps, the question arises, how to make use of the cavalry masses for strategic purposes. I have used the expression "direct security" advisedly, as the cavalry masses themselves, in the performance of their task of seeking information, will of course provide security indirectly, in a strategical sense. They can do this by meeting and defeating the cnemy's cavalry, and so preventing him from gaining information, and also by themselves discovering the positions and movements of the enemy's main forces, thus allowing the Chief to determine his plans with that security and certainty, of which good information is the only source.

The solution of the problem as to the strategical employment of cavalry is provided for us by history. Continental writers have made a close study of this subject; but I do not know of one book written in English dealing wholly with this most important matter.

I propose to give a summary of their conclusions, and then to briefly enter into the effect of their application, or the neglect of their application, as illustrated by the German cavalry in 1870 . 
The first conclusion is that the cavalry masses must be pushed far to the front in concentrated bodies, and on certain definite and well-defined strategical points. There must be nothing vague or general in the tasks that are allotted to these cavalry masses. The vague and general idea on this employment of cavalry, namely, the covering the whole front and flanks of an army with numberless small bodies of horsemen, advancing on every road and carefully maintaining lateral communication with each other, is a most pernicious one, and is contrary to every principle of strategy. Yet it is none the less a very prevalent idea. This misleading notion can, I think, be attributed to the frequent use of the expression "the cavalry screen," and also largely to the unfortunate formation that was laid down in our late "Cavalry Drill Book" for the performance of the socalled duty of "Streening aud Reconnaissance." As to the duty of screening by cavalry, I would like to say something later.

As regards the task of seeking information, the necessity of employing the cavalry concentrated is clearly recognised.

But if the cavalry be kept concentrated, they cannot be seeking for the enemy everywhere. The question which, then, has to be decided is: upon what points should these masses be directed? No rules can be laid down for this; and the answer to the question can only be found in the varying circumstances and requirements of each case, based on a thorough grasp of the strategical situation and a careful and close study of the map of the theatre of operations.

But as the role of the cavalry masses is to discover the main bodies of the enemy, and as these main bodies must be in the neighbourhood of certain important strategic points, the positions of which are usually decided by the junction of important roads and railways, and as Jarge bodies can only advance on the principal roads, it is these strategic points and principal roads which must be reconnoitred. $\mathrm{By}$ this method not all roads and places will be reconnoitred; but these will be the least important. Hostile patrols will thus, it is true, be able to pass unseen, but that cannot be avoided, and it will be the task of the service of "direct" security to stop them. The service of information must, before any other consideration, see everything that is possible. It must largely be left to the service of security to prevent the enemy seeing. The choice of the objectives upon which to direct the cavalry masses is one of the most important considerations which the Chief of the General Staff will have to settle, and it is one which can only be rightly and wisely decided upon by men who have made war generally and cavalry in particular a close and careful study in peace.

The next great principle to be decided upon is: to what distance shall these cavalry masses be pushed forward, and what limitations should be put on the range of their reconnaissance.

The answer to this is that, as a general rule, contact with the enemy should be the only limit set to the advance of cavalry masses, and that no limit in point of distance should be placed on them.

Cavalry employed on their great strategical rôle are now able to be entirely independent of the infantry columns marching in rear. Owing to their now being equipped with a good frearm and trained to use it, they are as powerful as the infantry for attack; and as a mass of cavalry will always have guns with it, the cavalry division must henceforth be regarded as a very mobile unit, combining tho 
powers, offensive as well as defensive, of the three arms. The fact is that they should be independent of the moves of their own army, but should be glued to the moves of the enemy's army; but by being independent of the moves of their own army, it must not be understood to imply that cavalry are not to be in communication with their own army. On the contrary, the.very raison d'etre of their being pushed far to the front is to gather information and pass it as rapidly as possible back to the General-in-Chief, and careful arrangements to this end must always be made.

The cavalry commander must only be told the object he is required to fulfil, which should be something of a definite nature, and having been given this, the number and length of his marches must be left entirely to his initiative, and to the obstacles which the enemy cau oppose to his movements.

On this question, Chabot, a well-known French writer on cavalry, points out that during the march of the Germans on Châlons, after Gravelotte, the army commanders appeared to lay down exact stages for the march of their cavalry divisions, who were kept only 12 to 15 miles in front of the infantry columns, and that this might have stultified the good work that was carried out by the cavalry during this period. The cavalry did their best to carry out their rôle by pushing officers' patrols and squadrons far to the front-in one case they were 42 miles ahead of the main body of the cavalry divisions. But, as he points out, this was only possible owing to the passive attitude adopted at this time by both the French cavalry and the inhabitants. If there had been any opposition these patrols would have required close support, which, as it was, they would not have got. The important thing during this advance was to learn the strength, positions, and movements of the French forces, which were known to be concentrating at Châlons, and to know it as soon as possible. The object being thus clearly defined, a mass of cavaliy should have been detailed to attain it, and, as Chabot says, "the cavalry for exploration should not have had its halting places fixed, nor normal and regular marches detailed, but should have only been told the object which it was required to attain."

That cavalry should be pushed forward into contact with the enemy at once nutst not, however, be taken as a hard and fast rule. There are occasions when this is undesirable, such as, for instance, when the great blow is being prepared, and it is essential not to warn the enemy of his danger. The campaign of 1805 on Ulm affords us an example. When the march of the Grand Army from the Main was just commencing, and before the Austrians in UIm were yet aware of it, Napoleon ordered his cavalry covering his advance not to pass a certain line for fear of prematurely alarming the Austrians. $A$ few days later, as we shall see, when his move had developed, and there was no longer a question of the secrecy of his presence, though there was a great question still of concealing and protecting the direction of his march, he changed his methods, and pushed a large body of cavalry on to Ulm and into immediate contact with the Austrians.

The question of raids by cavalry has been very largely diocussed; but like most operations of war, there are no hard and fast rules that can be laid down on the subject. The propititious moment for such raids and their objective depends entirely on the strategical situation, on the moral of the enemy and his commander, on the numbers-of 
the cavalry available, and, lastly but not least, on the results that may be hoped for from the raid.

There is one conclusion, however, that stands out clearly as a result of a study of the Anerican War of Secession, which is, that when an army is engaged in active operations against the enemy, it is not wise to deprive that army of its cavalry masses merely to harry and harass the enemy's communications. It is especially at such critical periods that the Chief has most need of his cavalry, both to discover the enemy's movements and to cover his own; and besides, a. body of cavalry merely riding across the communications of an army, burning a few storehouses, and tearing up a few miles of railway is a very different thing from placing across an eneny's communications a force which is strong enough to hold its own against determined attack. No one realised the vulnerability of his enemy's communications more than Napoleon, and no one struck more often at them, but it is interesting to note that he always struck with his main force, not with his cavalry; in fact, very much the reverse, for he employed his cavalry during these operations to keep in touch with the enemy's front and flank, and so cover the flauk marches of his main columns.

There are certainly two notable examples in the WVar of Secession of the disastrous consequences of detaching the mass of cavalry for the purpose of raiding the enemy's communications, when the main army was engaged in active operations, and these are the campaigns of Chancellorsville and Gettysburg. In the first case it was the Federal Chief, and in the sccond it was the Confederate Chief who committed the error, and both paid very dearly for it.

The great lessons to be learnt from these examples are, first, that though the cavalry mass must be entirely independent of the marches of the infantry columns, and may often have to make long detours, riding round the enemy's flank and into his rear and centre, yet the preservation of communication with the main army must always be maintained, or if interrupted, must be regained as soon as possible; and secondly, that the role of cavalry is essentially to gain information of the enemy's main forces, and that it must therefore be kept in close contact with them. In neither of these raids were the cavalyy so employed. On the contrary, they were as completely out of touch with the enemy's main forces as they were with their own army. In both cases the raiding cavalry were absent for several days, during which their respective Chiefs were in complete ignorance not only of their movements, but also-and this was the cause of disaster on each occasion-of the enemy's.

To cover and conceal the strategical manouvres of armies is also one of the most important duties which fall to the lot of the cavalry. This duty is often spoken of as screening, or putting out a cavalry screen, and I think the use of this term has led to some very erroneous ideas on this subject by people who have not considered the matter very deeply. It is popularly supposed that the cavalry screen is formed by a long cordon of small bodies of cavalry drawn across a stretch of country like a line across a blackboard; that it is a merc passive and defensive screen, a mere line of outposts, very often put out along some defensive line at a distance from the enemy.

But this is a very different method from the methods of Napoleon, Jackson, and Stuart, when their cavalry were required to carry out this great duty. They always used their cavalry actively; they made use of it to "mystify and mislead" the enemy. The first essential 
in using any force actively is to push it into contact with the enemy. The second essential is to keep it concentrated as much as possible.

It is very interesting to study Napoleon in 1805 during his advance against Mack at Ulm in regard to his cavalry screening his flank march.

Napoleon, as soon as he learnt that Mack had advanced to Ulm, saw the opportunity offered him of cutting Mack's communications, and thus bringing him to irretrievable ruin. Napoleon therefore did not march direct on Ulu, but struck at a point well in Mack's rear. This necessitated his marching past Mack, and it was essential to the success of this manœuvre that Mack should get no warning of it, and so retire out of the net before it definitely closed on him.

Napoleon also fully realised the danger of Mack boldly attacking him in flank during his mareh, and a further object of his cavalry screen was to give him ample warning of any such attempt. When Napoleon's main forces were $N$. and $N . W$. of Ulm, and it was still impossible for Mack to foresee the real direction of their further moves, which might very well have been direct on UIm itself, Napoleon pushed Murat down with 4 divisions of cavalry to within 13 to 20 miles north of Ulm, and during his further advance one of these Divisions, Bourcier's, was pushed still closer towards Ulm, and was kept there. This division was directed to push constant reconnaissances towards $\mathrm{Ulm}$, which reconnaissances were to proceed "as far as possible."

The result of this action was, that Mack was not only kept in ignorance of Napoleon's real objective, but was led to belicve that the cavalry to the north of Ulm was only the precursor of the main French Army advancing direct on the place.

Here we see no screen put out in the usual acceptance of tho word, but a large body of cavalry pushed down into contact with the enemy, and kept concentrated, and therefore always acting as a menace to the enemy. This contact was maintained by active reconnaissances, and not by a mere passive cordon of posts.

Jacķ̧on's methods of using his cavalry for this same purpose were very similar. On the 30 th April, 1862, when Jackson started to withdraw his main forces from in front of Banks, in order to concentrate with Jolnnson for an attack on Milroy, he left his cavalry under Ashby behind, to show a front to Bauks. This cavalry was not employed in any way as a passive screen; but on the 29th Ashby made a demonstration in force, and on the 30 th he drove the Federal cavalry back on their camps. On the 7 th May, the day before Milroy's defeat at McDowell, and when Jackson was 50 miles away as the crow flies and farther by the circuitous roads, Banks was under the impression that Jackson was advancing against him, and was at Harrisonburg. A few days previously he had been firmly convinced that Jackson was retreating to Richmond, but the real nature of Jackson's movement was never even guessed by him. During all this time, Ashby had been actively demonstrating against Bank's front.

If we turn to the German cavalry in 1870 , it is interesting to note to what extent they complied with the principles we have already touched upon, and to see, superior as their methods of employment were to the French, how far they really were from fulfilling their róle, and how slowly and gradually they arrived at the truth. 
The mobilisation of the three German Armies commenced on the 16th July, and in accordance with plans worked out long before, their concentration took place in the Palatinate, in the triangle, Treves-Lauterburg-Mayence. The first point to notice is the organisation and distribution of the cavalry. As already mentioned, the whole of the cavalry were divided up among the three armies, either as divisional cavalry or in 6 divisions and 5 brigades, which were attached to one or other of the three armies. There was no cavalry whatever retained as the special instrument of the headquarters, to be employed under the immediate command of the Chief. These divisions and brigades were distributed as follows:-Attached to the Ist Army was the 3rd Cavalry Division; with the IInd Army were 4 Cavalry Divisions, viz., the 5 th, 6th, 12th, and the Guard, and also the 25th Hessian Brigade; and attached to the IITrd Army were 4 brigades not organised into divisions, viz., a Cuirassier Brigade, a Uhlan Brigade, a Baden and a Würtemberg Brigade, and also the 4th Cavalry Division. That this distribution was faulty has already been noted. Moltke had determined to assume the offensive, and knowing the unpreparedness of the French scheme of mobilisation, he was anxious to make a decisive attack upon the French as soon as possible. With this object, the original points of detraining for the troops had been selected on the left bank of the Rhine, and as far to the front as was consistent with safety, so that there should be no unnecessary delay in the advance. Moltke's first step towards providing this safety, so necessary to enable the concentration of the axmies to be completed, was the inadequate method of placing along the frontier a very thin and immobile screen of all arms.

If the 100,000 French, who were available by the end of July, Lad arlvanced into the Palatinate, as Derrécagaix suggests, this screen would have been swept aside, and the whole German concentration might have been thrown back on to the right bank of the Rhine. Such a retrograde movement would have been an enormous gain in time for the French, and time, considering the backwardness of their preparation, was all-important for them at this moment.

On the 28th July, nine days after the declaration of war, the whole frontier of the Palatinate was only watched by 3 cavalry and 3 infantry brigades. Both Chabot and Cherfils, French writers who have made a close study of the use of the cavalry during this campaign, point out that the real instrument to provide this safety for the concentration, to secure the liberty of the Chief of mancuvres, and the necessary imformation upon which to base his manœuvres, was the cavalry mass, consisting of 6 divisions and 5 brigades. Yet so far were the Headquarters Staff from realising this, that the cavalry divisions were not the first troops to arrive at the rail-heads, and when they had arrived, they were still retained in rear, and no mass of cavalry was pushed to the front in order to protect and cover the concentration of the armies, or in order to discover what were the French dispositions and intentions.

And what were the consequences of this second misapprehension by the Headquarters Staff of the employment of their cavalry? News reached Berlin, through spies and the generosity (sic) of the French Press, that the mass of the French were concentrating at Metz. On account of this, cven though it had been foreseen, Moltke feared that an immediate advance of the French might fall upon the isolated heads of the IInd Army before its concentration was complete. 
He had taken no steps to ensure his "liberty of manœuvre," norto get early intelligence, for his weak and passive screen would only stop minor incursions, and it was incapable of pushing reconnaissances far enough through the enemy's advance posts to seek out the truth. It was only a service of security, not one of information. Moltkes. frame of mind in consequence passed from bold assurance to anxiety and uncertainty, and on the $23 \mathrm{rd} J u l y$, the IInd Army was ordered. to detrain on the Rhine, five or six marches from the frontier.

But if the mass of cavalry at his disposal had been concentrated and thrown across the frontier as soon as it was disposable, it would have discovered the dispositions of the French, and so relieved Moltke of much uncertainty, and allowed the advance to be concucted more in accordance with the actual situation; it would have fallen on the enemy's convoys, and attacked petty detachments, besides surprising and cannonading the larger camps. Such an advance of the cavalry masses would have also in all probability arrested the advance of the French into the Palatinate, which Moltke so dreaded, even if it had been ever intended.

By the 1st August the Ist Army was on the line Treves-Neunkirchen, still covered by a passive screen along the Saare. By the 3rd it had advanced some 12 to 26 miles towards Saarbriicken and Merzig, and during this advance the 3rd Cavalry Division had marched in rear, and on the night of the $3 \mathrm{rd}$ it camped between Loșheim and Lebach, between two infantry divisions.

So, far, this division, then, had entirely failed to cáry out its rôle. It would have been most usefully employed if it had explored the country between Thionville and Bouzonville. It would then havediscovered the presence of the 4 th French Corps at Boulay, and seen: that there were no signs of the French advancing.

Moanwhile the IInd Army, which was some distance in rear, commenced to advance on 1st August. Its Chief, Prince Frederick Charles, the only one of the three commanders who was a cavalry officer, used his cavalry more in conformity with true principles, for he ordered the 5th and 6th Cavalry Divisions forward to the frontier.

By the 3rd, the 5th Division had its three brigades posted within 16 to 6 miles of the Saare, and the 6th Division was at Klein Ottweiler, about 14 miles from the Saare, both divisions, however, having advanced at the rate of only 12 miles a day. From here the 6th despatched four squadrons on difierent recomnaissances, which established the fact that Saarbrïcken and Sarreguemines were both occupied.

On the 4th the main bodies of both divisions advanced some 6 miles, and various reconnaissances were pushed forward. A largeFrench camp was discovered at Bitche, and a patrol crossing the Saare at Volklingen slipped through the French posts and arrived on the rear of the IInd French Corps at Forbach. It saw a French column moving from Saarbriicken to St. Avold, and returned withoutfurther investigation. This report led to the erroneous belief that the French were retreating. On the 5 th further reconnaissances were sent out, which established the fact that the camps on the frontier were abandoned, and a movement appeared to be going on from Sarreguemines towards Bitche. During these first days of the war the employment of the cavalry of the IInd Army, though better than the measures adopted in the Ist and IIIrd Army, still fell far from the standard of perfection. 
Chabot, whose opinions are freely quoted in the French official account, remarks that, in the first place, more than half of the cavalry available were kept in rear, marching slowly with the infantry columns, who, let it be remembered, were already amply provided with. sufficient cavalry for their needs in the way of security. The 12 th and the Guard Division and the 25th Brigade should have been pushed to the front as well as the 5 th and 6 th Divisions, and the 4 divisions. might have been formed into one mass in order to break through into the heart of the French concentrations, clear up the situation, and spread alarm and uncertainty in the minds of the French commanders. A favourable line of advance for such an operation would have been round the French left flauk and down the valley of the Nied on Bouzonville and Boulay. The 2 divisions (the 5 th and 6th) that. were sent to the front, although united under command of one man, were not employed in a concentrated mass, but were spread out on a front of 30 to 36 miles; they were forbidden to advance further than within one short march of the frontier, and were actually ordered to perform only the duty of outposis. These divisions were never more than one march shead of the infantry, and they were kept for several days in the saww positions. They in fact performed the duties of the divisional cavalry, while the divisional cavalyy did nothing. The reconnaissances that were sent out did not remain in permanent. touch with the French, but returned every day to their corps. This resulted in false deductions being arrived at from what they had observed, and the same result will always ensue, if the observation of the enemy is not constant.

During this period, therefore, the German cavalry of the Ist. and IInd Armies only provided very superficial and inicomplete information, chiefly relating to contact with the French advanced posts, but no serious attempt was made to find out the positions of the French main forces. The cavalry failed therefore to carry out its róle; the information provided was inadequate and not sufficiently precise, and nothing was done to hamper in any way the concentration of the French. But let it be noted that this was not the fault of the cavalry. itself, but was the direct consequence of the orders of the army commanders.

The IIIrd Army, to which we have not yet referred, was concentrated between Landau and the Lauter, but neither the 4th Cavalry Division nor any of the 4 brigades attached to it were pushed to the front. The 4th Cavalry Division was in cantonments in rear of the army, and the 4 brigades were attached to certain corps and Divisions, and remained camped with them. Mixed outposts of cavalry and infantry were watching the frontier along the Luter, and through the agency of these troops the occupation of Weissenburg. by the Freuch was known.

The army advanced on the morning of the 4 th in several columns, and the only reconnaissance attempted was carried out by the divisional cavalry, who were of course tied to the heads of the infantry columns. Even in this case a large proportion of the divisional squadrons marched in rear.

Owing to bad strategy in pushing forward Douay's Division into Weissenburg, where it was exposed to the attack of 10 divisions, and also to tho careless way the French cavalry carriod out their reconnaissances on this date, this unfortunate division was crushed by the IIIrd Army after a very gallant resistance. When the moment for 
pursuit came, the ith Cavalry Division was far to the rear, and the officer sent to bring it up did not find it even as far forward as it ought to have been, owing to it having been delayed by finding another army corps marching across its route. In consequence, there was available for pursuit only the divisional cavalry and one brigade attached to the 1st Bavarian Corps. Even out of what there was, one regiment only was pushed on in pursuit, to Sulz, about 8 miles from Weissenburg.

This regiment found Sulz occupied, but not by troops who had been at the fight. It limited itself to this very insufficient reconnaissance, with the result that by that evening all touch with the defeated army had been lost, and the Germans were quite in the dark whether the French had retired on Bitche or Wörth. They were in complete uncertainty also as to the position of Marshal MacMlahon's corps.

Force of circumstances then obliged the headquarters of the IIIrd Army to employ their cavalry on sounder principles. The division was ordered to the front at 4 a.m. next day "to seek for the enemy in the direction of Hagenau, Suffelnheim, and Roppenheim," and a regiment was to be sent to Reichshoffen.

If one examines the map, one notes that in order to accomplish the object in view, which was to discover the position of MacMalion's corps, or the enemy's main force in this part of the theatre of war, there were only three roads which required to be reconnoitred, viz., those to Hagenau, to Reichshoffen, and to Bitche, for it was scarcely conceivable that the main forces of the French could be on the banks of the Rhine. Yet no recommaissance was directed on Bitche, and reconnaissances were ordered in directions which tho strategical situation should have shown were not very important. The reconnaissance of the 4th Division on this day did not result in much. One brigade was directed on Hagenau, where it was stopped by some infantry at a broken bridge, and, not being armed with firearms, the brigade retired, making no further efforts to discover what was the truth, and reported that a large force of infantry was concentrated at Hagenau! which was not true, as the place was only held by a few hundred men. Two squadrons, however, directed on Reichshoffen were fired on from Wörth, and saw the movements of large bodies of troops on the heights in rear. If this body of cavalry had been armed with firearms and had used them as the cavalry six years previously would have done (in the WVar of Secession), the opposition at Hagenau would have been broken down and the real facts of the rase laid bare.

Next day the battle of Wörth took place, during which the th Cavalry Division remained in its bivouac, 7 miles in rear! This was the result of orders direct from the IIIrd Army Headquarters, issued certainly, I admit, before it was intended to fight a battle; but what a conception of the employment of cavalry! It was intended to .fight a battle on the 7th August with the enemy's forces at Wörth, and the 6 th was to have been devoted to swinging the whole army to the right preparatory to the attack. But the information as to the extent of the enemy's position, his numbers, and the features of the ground generally were of the vaguest. During the 6th the cavalry division might well have been employed in advance, getting into touch with the enemy's front; working round his flanks, finding out 
where they rested, and if possible working in towards his rear to observe more closely his dispositions.

The study of this, and I may say of all great campaigns, shows us how absolutely necessary an intimate knowledge of the principles of the employment of cavalry is for the successful conduct of war. How far-reaching, in the way of success or in the way of disaster, are the consequences which ensue from the wise or from the stupid employment of this arm.

How often in reading history do we find gencrals, who did not know how to utilise their cavalry, who either left them behind like impedimenta, or on the other hand, dashed them off in every direction, imposing on them tasks they could not fulfil, with no regard to time or to their numbers or to their necessities.

Cavalry may be well commanded, well officered, well horsed, and numerous, and yet it may achieve nothing, entirely owing to stupid and ignorant orders from the Stafi at Headquarters.

It is most necessary therefore for all officers who aspire ever to command armies in the field to thoroughly understand the methods, the limitations, and the temperament of cavalry. It is the most delicate tool in the military workshop, and like all delicate tools, it demands from the man who uses it a thorough and expert knowledge.

Such knowledge is not born in man; it is only acquired by a close and diligent study of military history in peace. All officers therefore, of whatever arm of the Service, should make a special study of the use of cavalry, if we are to obtain from it anything like its full value.

Bul, in order that all the great and important tasks that fall to the lot of cavalry during a campaign may be carried out it must be numerous. Herein lies one of the most serious dangers which will beset our Army in the next great campaign it undertakes, namely, our appalling numerical weakness in cavalry. To give us anything like the proper proportion of cavalry to the other arms, we require at least 8 to 10 more cavalry regiments, and what the nation and her representatives who refuse to bear the cost should never forget is that when "serious dangers beset our Army in the next great campaign," that serious danger will beset the Empire also.

A rother important matter demanding the most careful consideration of the Chiefs of Armies and their Headquarters Staff, and therefore in an indirect way, of officers of all arms, who may any day find themselves on the Headquarters Staff, is the economical employment of cavalry. No arm goes to pieces so quickly if the horses are exposed to great hardships, or is so hard to re-form. Horses can make a great effort for short periods, but like all animals they require foot, and at times rest. These two requirements it must be the special study of the Headquarters Staff to see that they get.

It cannot be too often repeated that if you want to make use of your cavalry and not to destroy it, it is necessary, within judicious limits, to be most miserly in its use, never to employ a brigade when a squadron would suffice, never a squadron when a troop will do as well. Cavalry should only be employed when there is some useful object it can fulfl, and to attain this object only the absolutely recessary force should be employed.

This arm must be prepared to suffer quite as large a proportion of loss as the rest of the army in battle, but every effort must be made to prevent loss from unnecessary work, starvation, and exposure, 
which, ts a large extent preventible causes, have resulted in the destruction of the cavalry of an army far oftener than has direct loss from bullets.

Colonel Loxsdate Hale (late R.F.) :-My friend the lecturer had liardly finished his manuscript before he had to go away from the Staff College to foreign battle-fields, with a party of Staff College officers, and therefore he asked me to undertake the work, which was purely mechanical, and which I willingly mdertook, of passing his lecture through the press. The result is, that I hare read the lecture about three times, and the more I have read it, the more I have liked it, and perhaps I have noticed some things in it which hearers or readers of it for the first time might not detect. I must congratulate $m y$ friend, in the first place, on his powers of bitter irony and sarcasm.' If you will turn to his lecture, towards the end, you will see he says:- "It is most necessary therefore for all officers who aspire ever to command armies in the field to thoroughly understand the methods, the limitations, and the temperament of Cavalry. It is the most delicate tool in the military workshop, and like all delicate tools, it demands from the man who uses it a thorough and expert knowledge. Such knowledge is not born in man; it is only acquired by a close and diligent study of military history in peace. All officers, therefore, of whatever arm of the Service, should make a special study of the use of Cavalry, if we are to obtain from it anything .like its full value." Then, if you will turn back towards the beginning of the lecture you will see the author calmly tells the truth, that "Continental writers have made a close study of the strategical employment of Cavalry; but I do not know of one book, written .in English, dealing with this most important matter." That is exactly it, Sir ; that is exactly where wo fail. About ten years ago there came into power a school of instructors, who stated that the proper way to instruct the British Army was by the inculcation of principles only. Teach men principles, and leare them to apply them themselres. I :am the oldest teacher in the Army, not a D.A.G. for Instruction, but a common teacher, and I have been a teacher for many years, and I say that you will never teach anything by principles alone. You vo not teach a man to drive a locomotive by telling him the pripciples. You must gire concrete instances. The only way in which Cavalry officers can understand the working of this delicate machino is, by studying concrete instances of it-that is the only way. I speak from my own personal studx and many years' experience in this matter. If you want to grow old prematurely, try and trace out the work of a Cavalry division in all its ramifications in war-tine, down to the delicate springs the author Thas referred to. It not only requires enormous labour, but it requires a great amount of patience, and an aptitude for study. I will give my Cavalry friends the credit for possessing all that, but it wants more; it wants at the same time a command of two foreign languages, French and German. Even in the account of the work of a German Cavalry clivision you may not find sufficient details; you will have to take the regimental history and work away at all the patrols until you get what sou want. My friend the lecturer says "go and read." It is all very well for him to say "go and read," but how is the British officer to get hold of the documents? Colonel Gough and I at the Staff College can obtain the documents in the library there, but how is the British Cavalry officer t.J study and understand the working of this delicate machino when he has not the materials; and if he has not the command of two foroign 
Languages, how can he make anything out of the materials even if he has them?. I hold there has been a mistake on the part of the military authorities hitherto. I am speaking of the period prior to the South African War, when I say the lonest truth is, that the military authorities .did not believe in Cavalry; they had no sympathy with it. There was one great exception, Field-Marshal Sir Evelyn Wood; but if the others believed in or sympathised with Cavalry, all $I$ ean say is, that they kept their feelings remarkably under control. In old days, no Inspector-General of Caralry had the ear of the War Office, until Sir George Luck came, and he was the first Inspector-General who was erer listened to by the authorities at the-War Office. Had the authorities knomn about Caralry, or understood it, they would have deputed somebody to have drawn up the account of the working of the machine, with all its delicate springs, and would have spread it broadeast amongst the Cavalry. Perhaps, Sir, sou may have a possibility of exercising more influence, and therefore I say, until you have that done-not the achievements of Cavalry in the field, nothing of that sort-me can learn all about charges everywhere; but until you have Finglish books drawn up, giving an account in the minutest detail, of how the Cavalry perform all their important work in the Service, the British Cavalry officer camnot be expected to understand the working of the machine which it rests with him to work. The only thing is to provide the British officer with these detailed accounts, and let him study them. But even if you do that there is one class of -officer in the Cavalry that I do not think can, by any possibility, be raised to the discharge of the responsibilities which may fall upon them. I "use the word "may," not " do," because sometimes the responsibilities do not; but they may; and these are the young officers in the Cavalry. I do not know how the Cavalry subalterns are to be raised to the lerel of discharging those responsibilities which may ultimately fall upon them. I have to say this as a matter of etiquette to you, Sir, personally, but you known all about it. A Cavalry subaltern is sent out in front of an army with thrce or four troopers, and he is told to find out all about the enemy. If he is lucky, he may come across the eneny and get hold of a certain amount of data, although imperfect. On these data he has to form a conclusion as to what the enemy is doing, and that .conclusion he has to send to his Colonel or General behind, and on that the commanding officer, perhaps, bases his orders. It requires not merely the power of close observation. What is the good of officers knowing all these things unless they understand them? The officer must have an understanding of the phenomena which come before his eyes. Iet me take a case. I have already published it in a book; but it will not matter my repeating it, beeause nobody has read the book. Iset me take the case of Lieutenant ron Busse, of the 6th Caralry Divison. He was sent out in front of the Grand Duke of MecklenburgSchwerin's Detachment (Armec-Abtheilung) to find out about the French. He was a brare young fellow, and rode forward with ten men, and entered the town of Chateaudun, and found a large bods of French of all arms. He made his way out of the tomn, and after losing four men, got back to $a$ wood at night, and said to himself: "I will stop here for the night, and I will send in my report to-morrow after having looked again." That mas the failure. Had he known the strategical situation he might have said: "What on earth is the meaning of this great body of French troops here? Are they all going north to interrene between our Army and the Sccond Army, or are they going south, or are they stationary?" At all events, if he 
had had the strategical situation in his mind he would have seen that the mere fact of a large body of all arms being there was of the utmost importance, and the information should be sent back to his commanderas quickly as possible. But he did not do that. He said: "I will wait until to-morrow morning." What was the result of this young officer not grasping the situation? The Grand Duko commanding the army behind had heard of a body of troops marching north, and our soung lieutenant had hit on the main body due east of his own army. If the lieutenant's report had gone in that night, the Grand Duke might have marched duo east the next morning, and perhaps have swept that corps off the ground. As it was, owing to the delay of the young officer and his not realising the importance of the position, the Grand Duke marched north-east, and the whole of the enemy escaped him. I may mention another ease, which fortunately did not end in evil results. It was told to me by a Bararian Caralry officer, who was driving out with me when I was taking a friend to see the battle-fields on the east side of the Hoselle at Metz. My friend stopped the carriage and said: "I must tell you what took place here with regard to a subaltern of one of our Caralry regiments." He named a crack regiment of that time, not merely socially distinguished, but also extremely efficient. Ho said that at the time-just the time the lecturer has spoken of-the First Army were adrancing south towards Metz, tho Second Army was coming through the Vosges sonth-west towards Metz, and the Third Army were going straight west. It was of the utmost importance to them to know whether the lirench were still on the east side of the Moselle, and ready to receive them for battle. If so, they must close up their columns before they attacked them. If, on the other hand, the French had gone already, making for Verdum, they must go on as hard as they could, regardless of everything. This young subaltern was sent out. He looked around him, and hept his eyes and ears open, and came to the conclusion that the French Army had gone. Just think of the momentous result of that report. Everybody rould skurry on. Fortunately he had at some distance in the rear, the commander of the Cavalry Squadron, and the report had to go through him. Ho must have been an older man, and had possibly seen war in 1866 . He came up and he-looked at the indications which had presented themselves to the subaltern, and he came to the right and proper conclusion that the French Army was there, ready to receive the Germans at any moment, and he sent that information back. But the way he treated the subaltern was remarliable. He did not condemn him to that place which traditionally is the hottest place in the universe; he did not condemn him at all. He simply turned round to him and said: "The information which you have giren us, that there is no French Army here, is of the utmost importance, of vital importance, most intensely valuable, so raluable that you and $I$ will not let anyone else share it; wo will keep it to ourselres, and not send it on." Therefore, it did not go on. No, to meet the possible responsibilities old heads are needed, and rarely is tho old head to be found on the young shoulders of any subaltern. There is another point I should like to touch upon, and that is with regard to hanging on to the cnemy. I know nothing about the South African War or about India, but wo do find over and over again that Cavalry do not liang on even when they are in pursuit of, or trying to find, the enemy. Eren von Schmidt, who was the only Caralry general I think the Germans say the war produced, once lost touch with the enemy. But my friend, General von Wright, who commanded the Cavalry Dirision at Metz, an 
Linglishman, told me an anecdote of ron Schmidt which illustrates the spirit that should animate Cavalry in pursuit of the enemy. Von Schmidt had an awkward habit of turning out at night and going round the pickets and vedettes, and one night, when the enemy was supposed to be in front, he rode up to the picket and said to the picket com. mander: "Do you know anything about the enemy?" "No, sir." "Have you heard anything of the enemy?" "No, sir." "You do not know where he is?" "No, sir." "Very well, get on your horse and ride with mo and take me to the vedette." There he repeated the same qucstions: "Do you know where the enemy is?" "No, sir." "Heard anything of him?" "No, sir." "You know nothing about him ?" "No, sir." "Well, you ride on with me." They rode away into the darkness, and presently, bang, bang, a couple of chassepots whistled by the three of them. He turned round to the officer and said : "Young man, the next time I come to your picket and you know nothing about the enemy or where he is, I will have you tried by courtmartial and turned out of the Service." He turned round to the redette and said: "Young man, next time you give me those answers I will have you shot." I maintain that that is the true spirit of Cavalry officers. Thero is one other point I am very anxious to bring to your notice, and to the notice of the senior officers present. The question is: Will you have, with the Cavalry Division, infantry? I will not raise the question of mounted infantry, but infantry attached to it as part of the Cavalry Division. If anybody says "yes" or " no," I would ask at once the reason for the faith within them, and that would rather puzzle them, I think. This question was raised after the war of 1870 or 1871 . There was an enormous amount of military literature published on the subject, some saying that you ought to have infantry with you, and others that you ought not. In the year 1889 , it was considered desirable to sum up the discussion, and a long article appeared in the Militär-Wochenblatt, and there the writer, who dealt with the $4 t h$, 5th, and 6th Cavalry Divisions in the second.period of the rar, came to the conclusion that you ought not to have infantry except under rery exceptional circumstances; that if you have infantry you must have a great number of them to bo of any use, and then the result was, that you had your mobility diminished. But he did not go into a later period of tho war after the battle of le Mans. In January, after the battle, a large force with the 4th Cavalry Division went towards Alençon. The 4th Cavalry Division was on the exposed flank. They got into close country, and the division did not know whether it was likely it would be attacked from the west, or the north, or from the east. The men were employed all day long in reconnaissance in this difficult country. At night they had to set strong outposts, and the consequence was they rere working by night as well as day, and the result was that the men, not the horses, were knocked up. 'The general sent back for a battalion of infantry, the 44th legiment, and when these came up, the outpost night work of the Caralry ceased. The infantry were employed simply and solely for outpost picket duty at night. I am sorry to say, I do not see here my old friend of the Mounted Infantry; I had hoped he would be here for me to give him one. He would say : "I nish I had been there. I would have gone with my 600 men and horses." That is not what they wanted. They were very short of forage in that country, and they did not want 600 more horses. They brought these men over in wagons, four horses to trelve men, or in carts, two horses to six men, or one horse to every three men. In certain situations, it is a question whether an infantry 
battalion would not be useful. There is one sentence in the lecture that had burned itself into my mind, and if you will allow me, Sir, I will address it not to you, but to the young caralry officers who are in the audience. I have known caralry officers for a long time, and have been associated with them in manœures and that sort of thing, and $I$ an going to rend you a bit of a lecture. I do not know what your brains are like. There may be a meak point in them, as there is a weak point, one out of many, in this old skull of mine. When a thing is spoken to mo or I hear of it, I am very slow to realise it, but when $I$ do realiso it, I get the thing pretty tight. On the occasion of reading this lecture for the first time, I do not think I realised one sentence, and therefore I will read it to you, and I will read it slowly, so that you may listen to it and take it in. "Cavalry employed on that great strategical role are now able to be entirely independent of the infantry marching columns in the rear. Owing to their being equipped with a good fire-arm, and trained to use it, they are as powerful as the infantry for attack, and as a mass of Caralry will always have guns with them, a Cavalry Division must henceforth be regarded as a rery mobile unit, combining the porrers offensive as well as defensive of the three arms." Do you understand what that means, gentlemen? Do you realise what that Caralry Division means? It is the creation of a unit of which there does not exist, so far as I know, any parallel in the wars of past days. The Cavalry Division of the future combines in itself not only the powers of Cavalry, but the powers of Infantry and Artillery, and if you allow us Sappers to call ourselves the fourth arm, it combines the powers of the fourth arm as well. Just think of the power of that new unit! Take a concrete case. Tho the Cavalry Division rery late at night comes a very simple order. "The main body of the enemy is known to be collected at $A$. Between you and $A$, at $B$, is a hostile force of all arms." Then comes the order: "Go to $A$ and learn all about the eneny; destroy the force of B on your way." Nothing simpler than those orders. The Cavalry Division has to do it. . How is the Caralry Division to do it? It starts early in the morning, sending out scouts, and to the commander on the march comes in the report: "We have had to swim this river, the bridge is broken, there are plenty of materials to repair." There is no need to call on " mounted sappers" to do the work. Men of the Cavalry Division, "the cavalry pioneers," will go forward, repair the bridge, and make their own path. The Dirision goes on and arrives near the position of the enemy, and the general, linowing the position, determines on a combined frontal and flank attack. les, a flank attack; but time is of the greatest importance, and usually a flank attack means a long and veary jommey for the outflanking force, and keeping also touch with it. Here, however, is the flank attack ready in the minimum of time. A portion of the Division is sent off by various and hidden roads as fast as the lorses' legs can move, dropping as it goes its own relays of troopers to keep up comnumication, and to notify to the general its progress. And when all is ready, soldiers on foot, aided by gums, advance to tho attack. Yes, lut the soldiers on foot and the guns are parts of the Division itself; the men are merely off their horses, not on them. And now the general sees that his frontal attack is gaining ground; Cavalry Division orderlies bring him at mad gallop equally good news from the distant flank. Gradually the attack is pressed on, and the enemy warer, and at last eeem to break. Then comes the cry : "Where is the Cavalry?" Not miles away! as so often we hear of in past battles. They are the very 
men who have attacked. Up come their horses, and away they go and the enemy is destroyed. Think of that, you Caralry colonels; think what you have to work up to! Try and realise the glory of commanding a forco that has the powers of all the arms to do everything independent of the other arms! Think of it, and see whether you will not train your pioneers, your young subalterns, your squadron leaders, to meet every single emergency to fulfil every single duty that may fall upon them. Talk about the day of Cavalry being past! The day of Cavalry has just come, it lies before you in the immediate future, now that you have a firearm, and are not too proud to get domn and use it. You have your infantry, your Sappers, your Artillery, your Cavalry. Talk of a corps d'ćlitc. The corps d'élite of every army in the future will be the Cavalry Division of the army to which it belongs.

The Crrarmax (Major-General R. S. S. Baden-Powell, C.B.) :-It now becomes my painful duty to say a few words myself, as Colonel Gough has nothing to add to what he has said. I must say we have all enjoyed very much the stimulating vision which Colonel Lonsdale Hale has so eloquently put before us, of the great engine of war that Caralry is now likely to be. The drawback is, that for the moment it is a vision only, because we have not the numbers necessary. We can only hope that they will come in time. The lecturer has giren us a rery able exposition of the great value of Cavalry, and of its importance in the battle-field, provided, firstly, that it is well led, that is, that its leaders know their business; and secondly, that it is properly employed; that is to say, that the Commander-in-Chief of the army which uses it knows the value of his Caralry, and how to use it, understands its capabilities, and has the sense to give its leader a freo hand when he has once given him the object of his work. Colonel Gough remarks, that Caralry is the strategic arm, while Infantry and Artillery are tactical. Modern battlcs, as we see in the campaign now going on, hare grown from being merely a day's tactical operations, into a series of strategical moves of several days' duration over a ride extent of country. Thus, Caralry being a strategical arm, comes to be of far greater value than it ever was before. This form of action demands rery accurate recomnaissance, and a rery constant stream of information over wide tracts of comtry, and involves wide turning morements on the part of a mounted force-of a greater width than was ever before the case. Therefore, Caralry has a ralue it never liad before in helping the sister arms to win the battle. It is not the Cavalry that wins battles; the Infantry is the backbone of the whole thing; but Cavalry has its duties in helping the Infantry, and those are principally: firstly, the art of discorering, or recommaissance; secondly, the clearing away of the enemy's Cavalry from the front and flanks; and, thirdly, raids and enterprises. (When I talk of raids I do not mean the rery flash dashes that we have been accustomed to see at various times, which are generally aimless, raids such as the lectures. was referring to, as taking place at the important period about Chancellors. ville and Gettysburg, and raids such as we lave seen by De Wet in the Orange River Colony, and before that, in the rebellion of 1708 in Ireland, where Joseph Holt was exactly a prototype of De Wet. And perhaps, in this Manchurian campaign, Menchikow's dashes were aimless raids without any effect, beyond the destruction of a number of horses. What we want are well thought-out raids, with a real design about them, and then they become of enormous ralue to the army. Taking a smaller scale, the rery last example was that of the Japanese Caralry making 
its dash to Sin-min-ting.) The fourth duty the Caralry has in helping its sister Services is that of pursuit, which, to $\mathrm{my}$ mind, is one of the most important of all, because without Cavalry it is possible for Infantry and Artillery to win victories; but without Cavalry it is utterly im. possible for them to effect the absolute defeat of the enemy. If anybody could make defeat possible without the aid of Cavalry, $X$ think the Japanese were the men to do it, but they hare acknowledged to their regret that they had not sufficient force of Cavalry to make their victories into real defeats for the enemy. Had they had cavalry at LiaoIang, it would not have been merely a victory, it might have been a disaster for Russia. Had they had Cavalry at Mukden, it would have been something more than a big defeat; it might have been annihilation; it, would have been a second Sedan, or a Paardeberg on a very large scale. From the financial point of view, the cost of the extra Caralry in peace-time would have thus cansed a saring of many millions of war expenses. But I do not like preaching merely from one campaign, as an instance, because what I have said is a truism that goes back all through the history of Cavalry to the days of Xenophon, when he wrote the memorable words: "An army without Cavalry profits nothing by its victories, and loses all when defeated." The Japaneso realise this very fully. The loss they have suffered from the want of Caralry has been great. Cavalry; like the fleet, is not a thing you can organise suddenly. It must be "in being" at the time the war breaks out. It it not a thing that can be improvised at any time. Even although Infantry may be improvised during war behind the first line, as is being done now, yet Cavalry cannot be improrised during war, because its main work comes the very first day that war occurs. It is at the outset. that you want all your Cavalry, and therefore, it has to be prepared in peace-time. Again, we must not be led into the error of thinking that improvised corps of volunteers, howerer willing, are any use as Caralry at first. They cannot be used to supply the place of Caralry that is deficient in numbers and quality. We have innumerable instances of this, both in our own campaign in South Africa, and in the very similar campaign of the American War of Secession. These gare us convincing proofs that it does not do to use improrised, irregular, or volunteer Cavalry, in the place of real Caralry, trained in peace-time in the art of war. The Germaus now are realising, after all their study, that Cavalry is required more than ever; to their 485 squadrons, they are now adding 23 new ones, and the proportion thoy thus make with Caralry as compesed with Infantry, is about $\tilde{5}$ squadrons to every six battalions of Infantry. France has about 3 squadrons to every 5 battalions; Russia has 7 squadrous to every 12 battalions; and our proportion is about 9 squadrons to 22 battalions. That is a very small proportion; not, half what it should be. Then, again, our strength in units is so much below the others. A regiment of Cavalry with us comprises 3 squadrons. There is no other. country in the rorld that has less than 4 , and most of them have 5 or 6 . Again, a division with us includes 18 squadrons. With everybody else, 30 to 36 , nearly double the number. The Artillery in England, as in other countries, has been increased rery largely of late, to meet the modern requirements of war. The Caralry, which, in other countries, has been similarly increased, remains with us smaller than it was in the time of the Peninsula; but I think its tum is now coming. It really ought to be increased. Mounted Infantry can do a great deal to relieve Cavalry from the work, as Divisional Mounted Troops, of "corering" 
the arny, and so release it to carry out the advanced rork of "discorering" which the lecturer spoke of ; but even so, a large deficiency still remains in the strength of the Cavalry, which ought to be made up. $I$ believe it could bo begun at once by giving us a fourth squadron for every regiment, and by restoring to their place in the line the two grand old regiments, the 22nd and 23rd Light Dragoons. When we ask for more Cavalry, tro objections aro hurled at us. One is, that we cannot get officers for the regiments we have. I look on that as a rery temporary matter, because if you look back in history, you will see that such shortage is what occurred after the Waterloo campaign, after the Mutiny, and now again, after the South African War; and, I think, that with proper consideration given to the subject, as is being given now by a Committee, we shall find a way out of it, and a way of making the Service more acceptable to young officers. The examinations rather frighten them at present, and the pay and prospects are not so good as they might be; but doubtless that will be all looked into by the Committee. Also, parents seem unaware that an allowance of $£ 300$ will suffice to keep their son in any regiment. Again, the great cost of extra Caralry is rery much cavilled at. But we are apt to neglect to consider the great and grave danger that exists for this country. Although we get reassuring accounts from our statesmen and others, it is as well to read between the lines, and when one does so I must say it is a rery gloomy picture to look forward to. We have always to prepare for the possibility of rhat may happen, eren though it may seem improbable. When we consider that grare danger that is possible to this country, we ought to throw aside questions of expense. "It is better to spend in gaining strength than to be realthy-and weak." I have, perhaps, had better opportunities than most people here present during the last few montlis of comparing our Caralry with those abroad, because I have had the good fortune to go round a good many of them, and I hare seen the interior working of our own, and I can conscientiously say, that we are not very far behind in respect of quality and efficiency, although we are so in quantity. If we go on, at any rate, at the pace at which we are going on in Ireland, I think that after a vers short time, we shall be able to say that we are not behind ans of them. At least, I hope so. But in numbers, and in proportion to other arms, we are certainly dangerously small, and this is a fact which our fellow-countrymen will have to realise sooner or later, and the sooner the better for the national security of our country. Our thanks are due to the lecturer for bringing this subject forward so rery ably, and for putting his facts beforo us in such a very clear and interesting manner. I am rather an amateur at this business, and have nerer presided here before; but $I$ know it is usual for the lecturer, in having a rote of thanks accorded to him, to rise and thank his audience with becoming modesty; but, I think, it would be better if he not only thanked us in rords, but showed his appreciation by coming again and giving us another lecture in continuation of the same subject later on. I move a hearty rote of thanks to the lecturer for his kind serrice this afternoon. 